\title{
THE EFFECT OF CERTAIN PESTICIDES ON SOME PESTS INFESTING COWPEA AND THE YIELD CROP IN QUALYOBIA GOVERNORATE
}

\author{
FARGALLA, FARHA H. , E. A. M. MOUSA and A. F. E. AFSAH
}

Plant Protection Research Institute, ARC, Dokki, Giza

(Manuscript received 4 June 2012)

\begin{abstract}
Field experiment was carried out to evaluate the effect of four tested pesticides, namely Bio-fly $30 \times 10^{6}$ Cells/ $\mathrm{ml} \mathrm{L}$. and Biogard 6.4\% WP as biopesticides, Lannate $90 \%$ SP and Acron $72 \%$ EC as chemical pesticides in reducing the population of the most destructive pests attacking cowpea plant (Cowpea pod borer Etiella zinckenella Tr. , the leafminer liromyza trifolli (Burgess) and the whitefly Bemisia tabaci (Genn.) besides its affect on the number of associated predator Orius albidipennis(Reut.) and the total yield .

Data revealed that biopesticides can be used to minimize the pest populations and give a high total yield and did not affect the population of the predator.
\end{abstract}

\section{INTRODUCTION}

Cowpea plant is a trap to many destructive insect pests that severly effect the yield crop causing both quantitative and qualitative losses , Naito, and Masaki 1962, Dan Gerling g 1996 said that it is important to integrate the pest management systems to various crops with the preservation of their natural enemies. Information regarding the relative toxicity of pesticides to the natural enemies and in regarding to the exact methodology to be used for Bemisia tabaci management, especially in vegetable crops . Samia Metwally 1999 , stated that cowpea is attacked by many different serious pests.

Cowpea pod borer Etiella zinckenella, the leafminer liromyza trifolli and the whitefly Bemisia tabaci were found to be the most serious pests attacking cowpea plant . A field experiment was carried out in Quolyobia governorate to evaluate the effect of four pesticides namely : Bio-fly, Biogard, Lannate and acron, in minimizing the population of the widespread destructive pests, besides their effect on the associated predator, Orius albidipennis and to draw a comparison between the chemical and biopestcides in reducing the pests population and reduce the toxic residue for plant and environment. Elzen 2001 exposed laboratory reared predators, the insidious flower bug , Orius insidious (Say), and big eyed bug Geocoria punctiper (Say) to 10 insecticides there was considerable variation in response between both species tested to the insecticides . 
Muhammed et a/ 2005 revealed that the chemical control of insect pests is quick and rapid one and some soft insecticides such as regulators of insect growth are getting more attention of scientists as good substitute Abd El Ghany et al 2006 studied the effectiveness of four insecticides on immature stages of $B$ tabaci in bean fields and on the parasitoides that attack larvaeae and pupae of Esemocrus mundur and Encarsia lutea .

Gehan , Abdon et a/ 2006, a valuate the efficacy of some relatively safe compound beside the conventional pesticides for control of cowpea pests.

\section{MATERIALS AND METHODS}

The presented investigation was carried out at Kanater region , Qualyobia governorate during cowpea growing season of 2011 .

An area of about one fadden was cultivated with cowpea and divided into 20 plots to applied with four insect pesticides ( Table 1) namely Biofly 150 Cam / feddan , Biogard $500 \mathrm{~g} /$ fadden, Lannate $300 \mathrm{~g} /$ feddan and Acron 750 Cam / fadden . Four plots (replicates) for each treatment and four replicates were left without application to play the role of control.

Table 1. List of pesticide treatments .

\begin{tabular}{|l|c|c|}
\hline Tread name & common name & Concentration\&formulation \\
\hline Bio-fly & Beauveria bassiaana & $30 \times 10^{6}$ Cells/ ml L. \\
\hline Biogard & Bacillus thuringiensis & $6.4 \% \mathrm{WP}$ \\
\hline Lannate & Methomyl & $90 \% \mathrm{Sp}$ \\
\hline Acron & Profenfos & $72 \% \mathrm{EC}$ \\
\hline
\end{tabular}

Field treatments were conducted in randomizely for the four replicates. Pesticides were sprayed with $20 \mathrm{~L}$. knapsack sprayer, after one week of pesticides application cowpea leaves and pods were checked and examined to ensure the maintenance of the initial number of eggs counts and newly hatched larvae of $E$. zinckenella on checked pods, besides the mean numbers of $L$.trifalli mines , B. tabac nymphs and Orius albidipennis found on the cowpea leaves. Samples of 10 leaves and 10 pods were taken from each replicate to be examined in the laboratory. Thus, each pesticides was represented in 40 samples of both leaves and pods.

After the first week, 2 nd , 3 rd and 4 th week of application samples were examined to evaluate the reduction of pests population for the sucking pests, while for the $E$. zinckenella samples were taken for 5 weeks of application . 
Results were based on the alive individuals found in each sample. Percentage of reduction was estimated using the equation of Hinderson and Tilton (1955) .

To estimate and evaluate the total yield crop of each treatment, three replicates were recorded. Statistical analysis according to Fisher (1950) was carried out to evaluate the total yield of the crop between all tested treatments.

\section{RESULTS AND DISCUSSION}

Data presented in table (2) show the mean numbers of laid eggs of $E$ zinckenella $\mathrm{Tr}$. on cowpea pods before treatments besides the mean numbers of alive larvae feeding on seeds inside pods during the five interval weeks after treatment .

Data revealed the average numbers of alive laid eggs found on pods before treatment ranged from 4.0 to 6.2 eggs per pod, counted from mean number of 40 pods for each treatment besides 40 pods from control. After one week from application the mean numbers of alive larvae decreased to give means of $4.9,0.8,0.0$, 0.0 and 0.0 as a result of treatments with Bio-fly, Biogard, Lannat and Acron respectively, control was 5.4. Two weeks after treatment, the mean numbers of larvae infesting cowpea pods decreased sharply giving mean numbers of $0.1,0.5,1.2$, 0.7 and 3.1 individuals for Bio-fly, Biogarid, Lannate, Acron and control, respectively.

The mean numbers of $E$. zinckenella eggs infesting cowpea pods recorded a stable counts during the first week befor application, while the mean numbers of alive individuals began to increase rapidly by the season for the four tested pesticides giving mean numbers of 2.9, 1.8, 2.5 and 1.8 alive larvae per pods during the fifth week of treatment for the tested insecticides, respectively.

Regarding the percentages of reduction due to pesticides application , during the first week of application, Lannate and acron recorded $100 \%$ reduction for the newly hatched larvae of E. zinckenella, while bio-fly gave $32.67 \%$ and Biogard 88.04 $\%$, while after 2 weeks of application the results recorded higher rates of reduction gives $97.6 \%, 86.9 \%$ for Bio-fly and Biogard, respectively. On the other hand, Lannate and Acron recorded lower percentages of pest population reduction recording 69.81 and $74.0 \%$, respectively. After 5 weeks of application, the percentage of pest population reduction recorded 34.79, 55.98, 40.93 and 37.27, for Biofly, Biogard, Lannate and Acron, respectively.

Regarding the total percentages of reduction during the five tested weeks for tested insecticides, it was found that the percentages reduction recorded nearly same equal means $66.19,76.21,76.8$ and 69.3 for the four tested treatments, respectively . 
It is obvious that using either of the tested treatments may give same percentage of reduction in pest population. But being a biopesticide Biogared may be used safely to reduce the population pest.

Table (3) show the mean numbers of the leafminer Liromyza trifolli (Burgess) infesting cowpea leaves during four weeks after application with the four mentioned pesticides, besides the percentages of reduction due to each treatment.

Data revealed that during the first week of application Acron and Lannate gave the highest percentages of reduction in the pest population recording $61.99 \%, 60.62$ $\%$ respectively, while bio-fly gave the lowest percentages of reduction $22.67 \%$. Though by the season, Bio-fly and Biogared treatments recorded responsible high percentages of reduction recording 59.9, 47.51 and 59.33 during the second, third and fourth week of the pesticide application for Biofly , 62.81, 46.13 and 60.28 for Biogared treatment during the same weeks.

Data in table (4) represent the mean numbers of Bemisia tabaci (Genn.) nymphs found to be infesting leaves of cowpea plant before and after the application with Bio-fly, Biogared, Lannate and Acron besides the control. It is obvious that before treatment mean numbers of $B$. tabaci was relatively high ranged from 44.2 to 67.4 nymphs per leaf. During the first week of application the counts recorded 43.3, $23.2,11.1,15.1$ and 51.9 for the tested application and control, respectively, giving a considerable decrease for the pest population.

During the third week of treatment, it is clear that the mean numbers of $B$. tabaci nymphs began to increase giving the mean number of $39.2,22.7,38.1,32.9$ and 49.6 for the tested application and control, respectively.

Regarding the mean percentage of total reduction for the four pesticides application $63.5 \%$, $52.8 \%, 38.46 \%$ and $46.33 \%$ for Bio-fly, Biogard, Lannate and Acron, respectively, it can be said that using Biogared may give a reasonable reduction in the pest population.

As shown in the table the highest percentage of pest reduction $70.43 \%$ was recorded during the first week of application by Acron pesticides, while Biogared and lannate application gave moderate percentage of reduction $55.29 \%$ and $66.85 \%$.

However, by the season, Bio-fly application gave the highest reduction recording $63.5 \%$ meanwhile Biogared, Lannate and Acron recorded $52.8 \%, 38.46 \%$ and $46.33 \%$.

Regarding data in table (5) the reduction in orius sp. population as a predator associated with the serious pests infesting cowpea plant.

It is obvious that during the first week of application Acron treatment recorded a high reduction in the number of the predator $98.53 \%$, and it was $82.24 \%$ for 
Lannate treatment while, it was $17.58 \%$ and $15.87 \%$ for Bio-fly and Biogard treatment, respectively during the first week.

Concerning the mean percentage of reduction during the four weeks, it can be said that Bio-fly, Biagard , Lannate and acron , recorded $22.63 \%, 38.67 \%, 61.09 \%$ and $73.6 \%$

Thus, it could be said that Biogard and bio-fly may be used safely to maintain the predator number. Thus, as a results of the foregoing data, it could be concluded that using of the Bioinsecticides, my give a considerable reeducation for the 3 tested pests infesting cowpea plant, considering its safety for the environment and for the natural enemies.

Data presented in Table (6) show that the mean total yield of cowpea plant treated with the different tested pesticides during 2011 season in Qualyobia governorate, were $917.87,914.11,896.917,883.327$ and $712 . .00 \mathrm{Kg} /$ Fadden for Bio-fly, Biogard, lannate, acron and control, respectively . Obtained data revealed that bio-fly and biogared recorded the highest yield crop 917.870 and 914.110 respectively, while treated plants with a Acron gave the lowest yield . 
THE EFFECT OF CERTAIN PESTICIDES ON SOME PESTS INFESTING COWPEA AND THE YIELD CROP IN QUALYOBIA GOVERNORATE 
THE EFFECT OF CERTAIN PESTICIDES ON SOME PESTS INFESTING COWPEA AND THE YIELD CROP IN QUALYOBIA GOVERNORATE 


\section{REFERENCES}

1. Abd El Ghany, M. El Sayed and Mohamed, I. Shedeed. 2006. The effectiveness of some insecticides on the immature stages of whitefly Bemisea tabaci and its parasitoids in Been ( phaseollus vulgaris ) field. Nintl Arob Congress of plant protection .

2. Dan Gerling. 1996. Status of Bemisia tabaci in the Meaditerranean countries opportunities for Biollogical control . Biolgical control . 6,11-22 articlle No.022 .Faculty of life Science Tel oviv university .

3. Elzen G. W. 2001 . Lethal and subleyhol Effects of insecticide Residues on Orius insidiorus ( Hemiptera: anthocoridae ) and Geocoris puctipes (Hemiptera : Lygaidae). J. Econ. Entomol. 94 (1) 55-59 .

4. Fisher, R . A. 1950. Statistical methods for research workers . 11 Rev . Ed ., Olirver and Boyed, London .

5. Gehan , Y. Abdou and E. F. Abdalla 2006. Evaluation of some selected pesticides against the tow pod borer Helicoerpa armigera and Etella zinckenella population infesting cowpea in newly reclaimed Regions . Research Journal of agriculture and Biological Science , 2 (6).

6. Hinderson, C. F. and E. W. Tilton. 1955. Tests with a acaricids against the brown wheat mite. J . ecn . Entomal . , $48: 157-161$.

7. Muhammmed anjum Ali , Roliq . un Rehman , Yousaj Hussain Total and Zuliqar Ali. 2005. Evaluation of different insecticides for the control of whitefly on cotton crop in Karor District Loyyal pok . Entomol . Vol. 27 No.1.

8. Natio , A. and Masaki. 1962. Studies on the distribution of leno bean pod borer Etiella zinckenella rriet and soy bean pod borer Greabholitha glyci iniva. G . control agri . Sta. 2 : $145-228$.

9. Samia ,A . G . Metwally. 1999. Effect of planting date and certain weather factors on the population fluctuation on three insect pests infesting Kidnay beans in Qualybia governorate . Egypt, J. Agric . Res. < 77 (1) . 
تأثير بعض مبيدات الآفات على بعض ألافات التى تهاجم نبات اللوبيا وكذلك التأثر المنعكس على المحصول الناتج في محافظة القليوبية

فرحه حسنى فرج الله عصام على محمد موسى عبد الجابر فتوح السبد عفصه

$$
\text { معهز بحوث وقاية النباتات - مركز البحوث الزراعية - دقي - جيزة - مصر }
$$

اجري هذا البحث فى محافظة القليوبية عام 2011 بهدف تقييم أربعه مبيدات

و هى مركب البيو - فلاى - البيوجارد كمبيدات حيوية - اللانيت - اكرون كمبيدات

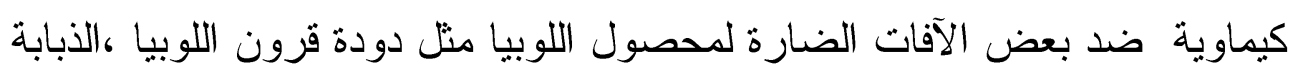

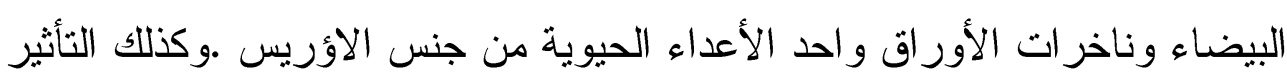
على المحصول .

أوضحت النتائج انه من الممكن استخدام المبيدات الحيوية لخفض تعداد الآفات

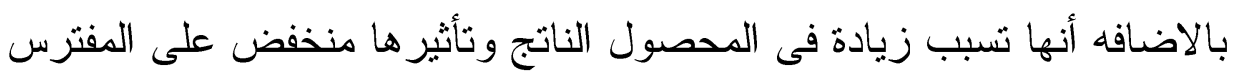

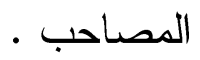

